in 1847. This exhibition, covering a century of mechanical engineering, is divided into several sections including mechanical plant for power stations ; locomotives; automobile, marine and aero-engines; hydraulic and handling machinery, etc. Important historical objects are shown in their appropriate galleries. Modern exhibits are displayed in Gallery 1. Scale-models made specially for this exhibition include the steam turbines of the R.M.S. Queen Elizabeth and a Southern Railway 'West Country' steam locomotive. Most exhibits, such as automobile and aero-engines, models of high-pressure boilers, steam and gasturbines, have never been shown in the Science Museum before.

\section{Conference on Liquid Helium}

A CONFEREnCE on liquid helium will be held at the Clarendon Laboratory, Oxford, during June 27-28. The programme includes discussions on the general and quantum theories of liquids (Prof. Max Born and Dr. H. S. Green respectively), the 'cage' model of a liquid (Dr. H. N. V. Temperley), zero-point energy of thin helium films (Prof. N. F. Mott), properties of helium films (K. R. Atkins, J. B. Brown and Dr. K. Mendelssohn) and Heisenberg's new theory of superconductivity (Prof. M. H. L. Pryce). Particulars of the conference can be ob tained from Prof. F. E. Simon, Clarendon Laboratory, Parks Road, Oxford.

Summer Symposium on Sound Absorption and Reverberation

The Acoustics Group of the Physical Society is holding a Summer Symposium on June 26 at the Royal Institute of British Architects. The discussions will open at 10 a.m. with a paper on "Panel Absorbents of the Helmholtz Type", by Prof. P. V. Bruel, of the University of Gothenburg. In the afternoon Mr. J. Moir, of the British Thomson-Houston Co., Ltd., will speak on "Reverberation Time as an Index of Room Performance". The meeting is open to all who are interested in acousties, but they are asked to notify the joint secretaries of the Acoustics Group at the offices of the Physical Society at 1 Lowther Gardens, Prince Consort Road, London, S.W.7, if they intend to be present, in order that necessary arrangements can be made.

\section{Scottish Summer Schools in Health Education}

$\mathrm{E}_{\mathrm{ACH}}$ year the Scottish Council for Health Education sponsors three residential summer schools at convenient centres. These schools are of interest to doctors, teachers, health visitors, nurses, youth leaders and others, who feel that integrated courses in physiology, psychology and social medicine will help them in their professional work. The schools are residential, last for fourteen days, and provide a total of twenty-seven lectures by men and women eminent in their special fields. Students may enrol for an elementary or intermediate course at the Universities of Edinburgh and St. Andrews, respectively, both from July 26 to August 9, or take an advanced course at Strathpeffer Spa during August 8-22. There are still a number of vacancies at the Edinburgh and St. Andrews schools, but only a very few at Strathpeffer, which, already, has attracted nearly a hundred students. Further information can be obtained from the Secretary, Scottish Council for Health Education, 3 Castle Street, Edinburgh, 2.

\section{University of London: Appointments}

THE following appointments in the University of London have been announced: Dr. Harry Jones, reader in mathematics at the Imperial College of Science and Technology, to the University chair of mathematics tenable at the College as from October 1, 1946 ; Dr. Alan Kekwick, to the University chair of medicine tenable at Middlesex Hospital Medical School as from October 1, 1946 ; Mr. M. E. L. Mallowan, to the University chair of western Asiatic archæology tenable at the Institute of Archæology as from May 1, 1947; Mr. Mallowan has conducted excavations at Arpachinah, the first settlement of the Tel Halaf culture to be scientifically excavated, also at Chagar Bazar and in the Tel Brak district; Dr. H. W. Miles, during 1943-46 adviser and senior lecturer in agricultural entomology in the University of Bristol, to the University chair of horticulture tenable at Wye College as from May 1, 1947 ; Mr. R. S. Sayers, during 1935-45 lecturer in economics at Pembroke, Exeter and Corpus Christi Colleges, Oxford, to the Sir Ernest Cassel chair of economics with special reference to banking tenable at the London School of Economics as from May 1, 1947; Mr. Herbert Tout, senior lecturer in economics at the University of Bristol, to the University readership in political economy tenable at University College as from October 1, 1947 ; Dr. W. J. Hickinbottom, since 1927 lecturer in chemistry in the University of Birmingham, to the University readership in organic chemistry tenable at Queen Mary College as from October 1, 1947; Dr. E. S. Horning, formerly of the permanent scientific staff at the Imperial Cancer Research Fund Laboratories, to the University readership in experimental pathology tenable at the Royal Cancer Hospital as from May 1, 1947 ; Dr. F. C. Tompkins, lecturer at King's College, to the University readership in physical chemistry tenable at the Imperial College of Science and Technology as from October 1, 1947.

The title of professor emeritus of chemistry in the University has been conferred on Dr. James F. Spencer on his retirement from Bedford College. The title of professor of comparative education in the University has been conferred on Dr. J. A. Lauwerys in respect of the post held by him at the Institute of Education.

The degree of D.Sc. has been conferred on O. V. S. Heath (Imperial College of Science and Technology); and S. S. Joski (University College).

\section{Announcements}

Sir LIONEL WHitBY, regius professor of physic in the University of Cambridge, has been elected master of Downing College, Cambridge, in succession to the late Sir Herbert Richmond.

A NATrONAL meteorological service has been established in Portugal under the direction of Prof. H. Amorim Ferreira. The headquarters of the new service is Serviço Meteorológico Nacional, Largo de Santa Isabel, 2-Lisboa (Portugal).

THE following officers were elected at the annual general meeting of the Society for Endocrinology held at University College, London, on May 29: Chairman : Dr. A. S. Parkes; Secretary: Dr. S. J. Folley, National Institute for Research in Dairying, Shinfield, Nr. Reading ; Treasurer : Dr. C. W. Emmens ; Editor of the Society's Proceedings : Prof. S. Zuckerman; Members of Committee : Dr. P. M. F. Bishop; Dr. C. H. Gray; Mr. P. C. Williams; Prof. F. G. Young.

Erratum. In the communication "TemperatureDependence of Magnetic Susceptibility of Annealed and Cold-worked Copper" (Nature, April 19, p. 537), par. 2, line 4, for " 0.005 per cent" read " 0.0005 per cent". 